\title{
HUBUNGAN PERILAKU HIDUP BERSIH DAN SEHAT DENGAN KEJADIAN DIARE DI WILAYAH KERJA PUSKESMAS DELANGGU
}

\author{
Titik Utari ${ }^{14}$, Pariawan Lutfi Ghazali ${ }^{15}$, Utami Mulyaningrum ${ }^{16}$
}

\begin{abstract}
Diarrhoea refers to discarding feces more than three time a day with the aqueous constitution. It is the $10^{\text {th }}$ most frequently reported disease. One of the developmental strategic of national heath to achieve The Health Indonesia in 2010 is implementing the health development with health oriented strategies, meaning, each program is supposed to yield the positive impact in shaping the healthy behavior and environmnet. The program of health and clean behavior represents the program which is aimed at providing the learning experience and creating conditions for individual, family, group, and society by opening the communication channel, providing information and performing education to improve the knowledge, attitude and behavior, thus; it raises the awareness, willingness, and readiness of society in practicing the clean and health behavior via advocacy approach, circumstance guidance and society empowerment. To identify the relation between behavior of healthy and clean life with the prevelance of diarrhoea in the working area of Delanggu Public Health Service. The research was observational, cross sectional study (non experimental). The research was conducted in working area of Delanggu Public Health Service. The sample comprised of people residing in working area of Delanggu Public Health Service. The data analysis adopted to process the data was Chi-Square and t-test with the significance level of $p=0.05$. The analysis included the variable analaysis of the presence of effect of independent variable on the dependent variable, which was later added with the description on the obtained results. The data wa analyzed by using computer program of chi square analysis and the significance value was 0.000 . since $p<0.05$, it was concluded that there was relation between behavior of healthy and clean life with the prevalence of diarrhoea in the working area of Delanggu Public Health Service. The magnitude of correlation between clean and healthy behavior was 0.540 , indicating the moderate correlation. T-test yielded the value of $p=$ 0.000 , meaning that at alpha $5 \%$, there was difference siginificant average score of clean and healthy behavior betwen those with diarrhoea and those without diarrhoea. The average score of clean and healthy behavior of the diarrhoea sufferers was lower that of clean and healthy behavior without diarrhoea. There was a siginificant relation between behavior of healthy and clean life with the prevalence of diarrhoea in the working area of Delanggu Public Health Service. There was a siginificant average score of clean and healthy behavior between those with diarrhoea and those without diarrhoea.
\end{abstract}

Key words : Behavior of healthy and clean life, Environment, Chi square, T-test

\section{ABSTRAK}

Program Perilaku Hidup Bersih dan Sehat merupakan program yang bertujuan memberikan pengalaman belajar atau menciptakan suatu kondisi bagi perorangan, keluarga, kelompok dan masyarakat dengan membuka jalur komunikasi, memberikan informasi dan melakukan edukasi untuk meningkatkan pengetahuan, sikap dan perilaku sehingga masyarakat sadar, mau, dan mampu mempraktekkan Perilaku Hidup Bersih dan Sehat melalui pendekatan advokasi, bina suasana dan pemberdayaan masyarakat. Perilaku hidup bersih dan sehat seseorang dapat berhubungan dan meningkatkan kesehatan individu, keluarga, masyarakat dan lingkungannya. Perilaku hidup bersih dan sehat seseorang diduga mempunyai hubungan terhadap kejadian diare di wilayah kerja Puskesmas Delanggu. Mengetahui hubungan perilaku hidup bersih dan sehat dengan kejadian diare di wilayah kerja Puskesmas Delanggu. Jenis penelitian merupakan studi observasional (non eksperimental) dengan rancangan penelitian cross sectional. Populasi dalam penelitian ini adalah seluruh warga yang berdomisili di wilayah kerja Puskesmas Delanggu. Sampel penelitian ini adalah sebagian dari populasi yang berdomisili di wilayah kerja Puskesmas Delanggu. Cara pengambilan sampel dari populasi digunakan sampling acak. Analisis data yang digunakan untuk pengolahan data penelitian ini adalah dengan uji Chi-Square dan $t$ test, dengan taraf kemaknaan $\mathrm{p}=0,05$ atau tingkat kepercayaan $95 \%$. Data diperoleh dari 100 responden, 11 orang termasuk dalam kategori PHBS Sehat Pratama, 15 orang Sehat Madya, 36 orang Sehat

\footnotetext{
${ }^{14}$ Fakultas Kedokteran Universitas Islam Indonesia

${ }^{15}$ Departemen IImu Kesehatan Masyarakat Fakultas Kedokteran viniverstas is am indonesia

${ }^{16}$ Departemen Patologi Klinik Fakultas Kedokteran Un vers tas slam Indonesa
} 
Utama dan 38 orang Sehat Paripurna. Data dianalisis dengan program komputer dan didapatkan nilai kemaknaannya adalah 0,000 . Oleh karena $p<0,05$, maka dapat diambil kesimpulan bahwa terdapat hubungan antara perilaku hidup bersih dan sehat dengan kejadian diare di wilayah kerja Puskesmas Delanggu. Besar kekuatan korelasi antara perilaku hidup bersih dan sehat adalah sebesar 0,540 yang menunjukkan korelasi sedang. Rata-rata skor PHBS yang terkena diare adalah 8,74 dengan standar deviasi 2,700. Sedangkan yang tidak menderita diare, rata-rata skor PHBS-nya adalah 11,53 dengan standar deviasi 2,894. Hasil uji statistik $T$-test for mean didapatkan nilai $p=0,000$, berarti pada alpha $5 \%$ terlihat perbedaan yang signifikan rata-rata skor PHBS antara yang terkena diare dengan yang tidak terkena diare. Rata-rata skor PHBS penderita diare lebih rendah daripada skor PHBS yang tidak menderita diare. Ada hubungan yang bermakna antara Perilaku Hidup Bersih dan Sehat dengan kejadian diare di wilayah kerja Puskesmas Delanggu, dengan taraf hubungan sedang. Rata-rata skor PHBS (Perilaku Hidup Bersih dan Sehat) yang terkena diare lebih rendah secara signifikan daripada yang tidak terkena diare.

Kata kunci : Perilaku Hidup Bersih dan Sehat, Lingkungan, Chi square, T-test

\section{PENDAHULUAN}

WHO (2004) menyebutkan diare terjadi di seluruh dunia dan menyebabkan $4 \%$ dari semua kematian. Secara umum disebabkan oleh infeksi gastrointestinal dan membunuh sekitar 2.2 juta orang setiap tahun, kebanyakan dari mereka adalah anak-anak di negara berkembang.

$$
\text { Dinkes Kabupaten Klaten (2003) }
$$

melaporkan, bahwa penyakit diare berada pada peringkat kedua dari 10 besar penyakit tahun 2003. Padahal pada tahun 2003 telah terjadi penurunan sebesar 8.213 yaitu dari 29.523 penderita pada tahun 2002 menjadi 21.310 penderita. Hal ini kemungkinan disebabkan karena adanya pola makan yang baik, perilaku hidup bersih dan sehat yang mulai memasyarakat dan peningkatan pengetahuan penduduk tentang kesehatan.

Keadaan sanitasi yang masih belum memadai seperti di Indonesia mengakibatkan penyakit diare, terutama yang ditularkan melalui air dan makanan senantiasa merupakan masalah utama kesehatan masyarakat. Hal ini dapat dilihat dari tingginya angka kematian dan

kesakitan diare, terutama pada bayi dan balita. Dari daftar urutan penyebab kunjungan Puskesmas, diare hampir selalu masuk 3 alasan utama masyarakat berkunjung ke puskesmas (Departemen Kesehatan [Depkes], 2002).

Memasuki millenium baru Departemen Kesehatan telah mencanangkan Gerakan
Pembangunan Berwawasan Kesehatan, yang dilandasi paradigma sehat. Paradigma sehat adalah cara pandang, pola pikir atau model pembangunan kesehatan yang bersifat holistik, melihat masalah kesehatan yang dipengaruhi oleh banyak faktor yang bersifat lintas sektor, dan upayanya lebih diarahkan pada peningkatan, pemeliharaan dan perlindungan kesehatan. Secara makro paradigma sehat berarti semua sektor memberikan kontribusi positif bagi pengembangan perilaku dan lingkungan sehat, sedangkan secara mikro berarti pembangunan kesehatan lebih menekankan upaya promotif dan preventif tanpa mengesampingkan upaya kuratif dan rehabilitatif (Depkes, 2002).

Berdasarkan parad' jma sehat ditetapkan visi Indonesia Sehat 201C, dimana ada 3 pilar yang diutamakan, yaitu lingkungan sehat, perilaku sehat dan pelayanan kesehatan yang bermutu, adil dan merata. Untuk perilaku sehat dapat dicerminkan dengan perilaku proaktif memelihara dan meningkatkan kesehatan, mencegah resiko terjadinya penyakit serta berpartisipasi aktif dalam kesehatan.

Indonesia Sehat 2010 merupakan visi pembangunan kesehatan yang bertujuan memberikan gambaran yang ingin dicapai masyarakat Indonesia pada masa mendatang. Untuk itu telah ditetapkan misi pembangunan, yaitu menggerakkan pembangunan nasional berwawasan kesehatan, mendorong kemandirian 
masyarakat untuk hidup sehat, memelihara dan meningkatkan pelayanan kesehatan yang bermutu, merata dan terjangkau serta memelihara dan meningkatkan kesehatan individu, keluarga, masyarakat beserta lingkungannya.

Depkes (2001), mengemukakan seiring dengan cepatnya perkembangan dalam era globalisasi, serta adanya transisi demografi dan epidemiologi penyakit, maka masalah penyakit akibat perilaku dan perubahan gaya hidup yang berkaitan dengan perilaku dan sosial budaya cenderung semakin kompleks. Mengingat dampak dari perilaku terhadap derajat kesehatan cukup besar, maka diperlukan berbagai upaya untuk mengubah perilaku yang tidak sehat menjadi sehat. Salah satunya melalui program Perilaku Hidup Bersih dan Sehat (PHBS).

Program Perilaku Hidup Bersih dan Sehat merupakan program yang bertujuan memberikan pengalaman belajar atau menciptakan suatu kondisi bagi perorangan, keluarga, kelompok dan masyarakat dengan membuka jalur komunikasi, memberikan informasi dan melakukan edukasi untuk meningkatkan pengetahuan, sikap dan perilaku sehingga masyarakat sadar, mau, dan mampu mempraktekkan Perilaku Hidup Bersih dan Sehat melalui pendekatan advokasi, bina suasana dan pemberdayaan masyarakat. Dengan demikian masyarakat dapat mengenali dan mengatasi masalahnya sendiri terutama pada tatanannya masing-masing, di mana ada 5 tatanan Perilaku Hidup Bersih dan Sehat yaitu rumah tangga, sekolah, tempat kerja, sarana kesehatan, dan tempat-tempat umum. Program Perilaku Hidup Bersih dan Sehat tersebut memiliki 5 Program prioritas yaitu Kesehatan Ibu dan Anak (KIA), Gizi, Kesehatan Lingkungan, Gaya Hidup, dan Dana Sehat / Askes / JPKM.

Program Perilaku Hidup Bersih dan Sehat dalam perkembangannya dan sesuai dengan dinamika yang terjadi di masyarakat menunjukkan jumlah dan jenis indikator Perilaku
Hidup Bersih dan Sehat yang di gunakan oleh masing-masing daerah sangat bervariasi, sesuai kondisi dan kebutuhan daerah masing-masing seiring dengan berlakunya otonomi daerah. Pusat Promosi Kesehatan sampai saat ini telah menetapkan 9 indikator perilaku dan 7 indikator lingkungan di tatanan rumah tangga. Indikator perilaku tersebut adalah tidak merokok, pertolongan persalinan oleh tenaga kesehatan, imunisasi, penimbangan balita, gizi keluarga / sarapan, kepesertaan Asuransi Kesehatan (Askes) / Jaminan Pemeliharaan Kesehatan Masyarakat (JPKM), mencuci dengan sabun sebelum makan dan sesudah buang air besar, menggosok gigi sebelum tidur dan olah raga / aktivitas fisik. Indikator lingkungan tersebut adalah ada jamban, ada air bersih, ada tempat sampah, ada Sistem Pembuangan Air Limbah (SPAL), ventilasi, kepadatan, lantai bukan tanah.

Di Indonesia seperti halnya di negaranegara berkernbang lainnya, menurut Soemirat (2000) masalah kesehatan lingkungan misalnya perumahan, pembuangan kotoran (tinja), penyediaan air bersih, pembuangan sampah dan pembuangan air limbah berpengaruh terhadap kesehatan masyarakat, terutama tingginya penyakit infeksi.

Berdasarkan uraian tersebut di atas, bahwa perilaku hidup bersih dan sehat seseorang dapat berhubungan dan meningkatkan kesehatan individu, keluarga, masyarakat dan lingkungannya. Perilaku hidup bersih dan sehat seseorang diduga mempunyai hubungan terhadap kejadian diare di wilayah kerja Puskesmas Delanggu.

Berdasarkan uraian dalam latar belakang masalah tersebut di atas, pertanyaan penelitian yang diajukan dalam penelitian ini adalah "apakah perilaku hidup bersih dan sehat berhubungan terhadap kejadian diare?". Penelitian ini bertujuan untuk mengetahui hubungan perilaku hidup bersih dan sehat 
dengan kejadian diare di wilayah kerja Puskesmas Delanggu.

\section{BAHAN DAN CARA PENELITIAN}

Jenis penelitian merupakan studi observasional (non eksperimental) dengan rancangan penelitian cross sectional. Analisis ini menyangkut analisis variabel ada tidaknya pengaruh variabel independen terhadap variabel dependen, yang kemudian akan ditambah dengan deskriptif mengenai hasil yang diperoleh.

Populasi dalam penelitian ini adalah seluruh warga yang berdomisili di wilayah kerja Puskesmas Delanggu. Sampel penelitian ini adalah sebagian dari populasi yang berdomisili di wilayah kerja Puskesmas Delanggu, yaitu sebanyak 100 orang.

Metode dalam pengambilan data pada sampel penelitian ini digunakan sampling. Cara pengambilan sampel dari populasi digunakan sampling acak.

Rumus untuk menentukan ukuran sampel adalah sebagai berikut :

$$
n=\frac{(z \alpha)^{2} P Q}{d^{2}}
$$

$\mathrm{P}=$ proporsi penyakit atau keadaan yang akan dicari

$Q=(1-P)$

$d=$ tingkat ketepatan absolut yang dikehendaki (ditetapkan peneliti)

$\alpha=$ tingkat kemaknaan

$$
\begin{aligned}
n & =\frac{(1,96)^{2}(0,5)(0,5)}{(0,1)^{2}} \\
& =\frac{4(0,25)}{0,01} \\
& =100
\end{aligned}
$$

Dari hasil perhitungan tersebut maka jumlah sampel yang digunakan pada penelitian minimal 100 orang.
Variabel penelitian ini adalah:

1. Variabel bebas/independen, yaitu Perilaku Hidup Bersih dan Sehat (PHBS)

2. Variabel tergantung/dependen, yaitu Diare

3. Variabel pengganggu, yaitu usia, jenis kelamin, status ekonomi, dan tingkat pendidikan

Identifikasi subjek penelitian diawali dengan pengumpulan data sekunder dari Puskesmas Delanggu mengenai survei Perilaku Hidup Bersih dan Sehat yang dilakukan terakhir kali. Kemudian peneliti melakukan observasi keadaan kesehatan lingkungan rumah tangga dan menjadikannya sampel penelitian, untuk selanjutnya diikutsertakan dalam penelitian. Data juga diambil dengan melakukan wawancara kepada subjek penelitian.

Analisis data yang digunakan untuk pengolahan data penelitian ini adalah dengan uji Chi-Square dan $t$ test, dengan taraf kemaknaan $p=0,05$ atau tingkat kepercayaan $95 \%$.

Dalam penelitian ini, peneliti menggunakan indikator Perilaku Hidup Bersih dan Sehat dari Departemen Kesehatan. Indikator tersebut terdiri dari 16 pertanyaan, sebagaimana tersebut di atas. Selain indikator tersebut, peneliti juga menggunakan daftar pertanyaan untuk mengetahui kejadis i diare dalam satu bulan terakhir.

\section{HASIL PENELITIAN}

Kecamatan Delanggu terletak di sebelah utara dari wilayah Kabupaten Klaten, di pinggir jalan raya Yogyakarta-Solo dengan batas wilayah sebelah utara Kecamatan Wonosari, sebelah selatan Kecamatan Ceper, sebelah barat Kecamatan Polanharjo, sebelah timur Kecamatan Juwiring.

Luas daerah Kecamatan Delanggu adalah 1.889,07 Ha. Kependudukan Kecamatan Delanggu terdiri dari 16 desa, 102 dusun / dukuh dengan 104 Rukun Warga (RW) dan 307 Rukun Tetangga (RT). 


\section{Hubungan Perilaku Hidup Bersih dan Sehat}

Luas pertanahan Kecamatan Delanggu sebagian besar berupa persawahan kemudian bangunan dan selanjutnya disajikan dalam tabel
Cakupan penggunaan air bersih yang dicapai sebesar $78 \%$ dari angka standar yang ditetapkan sebesar $75 \%$. Cakupan penggunaan jamban yang

Tabel 1. Distribusi Luas Pertanahan Kecamatan Delanggu.

\begin{tabular}{lr}
\hline \multicolumn{1}{c}{ Pertanahan } & Luas (Ha) \\
\hline Persawahan & $1.346,62$ \\
Ladang & 49,95 \\
Bangunan \& pertokoan & 409,36 \\
Lain-lain & 83,14 \\
Jumlah & $1.889,07$ \\
\hline
\end{tabular}

Sumber :Laporan Tahunan PPKKS Delanggu Tahun 2003

Tingkat pendidikan pada penduduk di Kecamatan Delanggu sangat bervariasi dan selengkapnya dapat dilihat pada tabel 2. dicapai sebesar 38\% dari angka standar yang ditetapkan sebesar 65\%. Cakupan penggunaan SPAL (Saluran Pembuangan Air Limbah) yang

Tabel 2. Distribusi Penduduk Menurut Tingkat Pendidikan.

\begin{tabular}{lcc}
\hline \multicolumn{1}{c}{ Pendidikan } & Jumlah & Prosentase \\
\hline Buta huruf & 0 & $0 \%$ \\
Baca Tulis / DO SD & 11.520 & $35,19 \%$ \\
Lulus SD & 11.520 & $35,19 \%$ \\
Lulus SLTP & 4.343 & $13,3 \%$ \\
Lulus SLTA & 4.980 & $15,21 \%$ \\
Lulus Akademi / PT & 376 & $1,16 \%$ \\
\multicolumn{1}{c}{ Jumlah } & 37.739 & \\
\hline
\end{tabular}

Sumber :Laporan Tahunan PPKKS Delanggu Tahun 2003

Jumlah penduduk Kecamatan Delanggu menurut tingkat pendidikan yang merupakan lulusan terbanyak adalah tingkat pendidikan dicapai sebesar $49 \%$ dari angka standar yang ditetapkan sebesar $51 \%$. Dari variabel kesehatan lingkungan tersebut, dapat dilihat yang belum

Tabel 3. Distribusi Pekerjaan Penduduk Kecamatan Delanggu

\begin{tabular}{cc}
\hline Pekerjaan & Jumlah \\
\hline Buruh tani & 5539 \\
Tani pemilik tanah & 2725 \\
Pedagang & 1255 \\
PNS & 1387 \\
ABRI & 446 \\
Pensiunan & 520 \\
\hline
\end{tabular}

Sumber : Laporan Tahunan PPKKS Delanggu Tahun 2003

Lulus SD yaitu sebanyak 35,19\%.

Penduduk Kecamatan Delanggu, sebagian besar pekerjaannya adalah buruh tani. memenuhi syarat dalam cakupan kesehatan lingkungan Kecamatan Delanggu adalah cakupan jamban keluarga dan cakupan SPAL. 
Tabel 4. Frekuensi Perilaku Hidup Bersih dan Sehat dengan kejadian diare di wilayah kerja Puskesmas Delanggu

\begin{tabular}{ccccccc}
\hline & \multicolumn{2}{c}{ Diare $(+)$} & \multicolumn{2}{c}{ Diare $(-)$} & \multicolumn{2}{c}{ Total } \\
\cline { 2 - 7 } & $f$ & $\%$ & $f$ & $\%$ & $f$ & $\%$ \\
\hline Sehat Pratama & 5 & 5 & 6 & 6 & 11 & 11 \\
Sehat Madya & 14 & 14 & 1 & 1 & 15 & 15 \\
Sehat Utama & 14 & 14 & 22 & 22 & 36 & 36 \\
Sehat paripurna & 1 & 1 & 37 & 37 & 38 & 38 \\
Total & 34 & 34 & 66 & 66 & 100 & 100
\end{tabular}

Hasil penelitian ini merupakan hasil dari 100 indikator, terdiri dari 16 pertanyaan yang dibagikan dan wawancara kepada masyarakat yang berdomisili di wilayah kerja Puskesmas Delanggu.

Gambaran karakteristik responden bervariasi. Dari 100 responden diperoleh data jenis kelamin dan tingkat pendidikan. Responden dalam penelitian ini kebanyakan berjenis kelamin pria yaitu: $79 \%$ (79 responden) dan sisanya $21 \%$
Sehat Madya, 36 orang Sehat Utama dan 38 orang Sehat Paripurna.

Tabel 4 diatas memenuhi uji chi square sehingga data dapat dianalisis dengan program komputer dan didapatkan nilai significancynya adalah 0,000 . Oleh karena $p<0,05$, maka dapat diambil kesimpulan bahwa terdapat hubungan antara perilaku hidup bersih dan sehat dengan kejadian diare di wilayah kerja Puskesmas Delanggu. Besar kekuatan korelasi antara

Tabel 5. Distribusi rata-rata skor PHBS antara yang terkena diare dan yang tidak diare.

\begin{tabular}{cccccc}
\hline Variabel & Mean & SD & SE & P value & N \\
\hline Diare (+) & 8,74 & 2,700 &, 463 & 0,000 & 34 \\
Diare (-) & 11,53 & 2,894 &, 356 & 66 \\
\hline
\end{tabular}

(21 responden) berjenis kelamin wanita. Responden dalam penelitian ini rata-rata berpendidikan Sekolah Menengah Pertama (SMP) dan Sekolah Menengah Umum(SMU) yaitu sebesar 40\% (40 responden) dan 41\% (41 responden). Responden yang berpendidikan Taman kanak-kanak terdapat 1\%, Sekolah dasar (SD) sebesar $11 \%$ dan yang berpendidikan sarjana (Perguruan Tinggi) terdapat 7\%..

Jumlah keseluruhan indikator yang dibagikan telah memenuhi syarat untuk digunakan sebagai sampel. responden.

Hasil pada tabel 4 diperoleh dari 100

Dari tabel di atas diketahui bahwa dari 100 responden diperoleh 11 orang termasuk dalam kategori PHBS Sehat Pratama, 15 orang perilaku hidup bersih dan sehat adalah sebesar 0,540 yang menunjukkan korelasi sedang.

Selain dengan uji chi square, juga dilakukan analisis data dengan menggunakan $t$ test untuk mengetahui apakah terdapat perbedaan yang signifikan skor PHBS antara yang diare dan tidak diare.

Rata-rata skor PHBS yang terkena diare adalah 8,74 dengan standar deviasi 2,700 grm\%. Sedangkan yang tidak menderita diare, rata-rata skor PHBS-nya adalah 11,53 dengan standar deviasi 2,894. Hal ini dapat dilihat selengkapnya pada tabel 5. Hasil uji statistik didapatkan nilai $p=0,000$, berarti pada alpha $5 \%$ terlihat perbedaan yang signifikan rata-rata skor PHBS antara yang terkena diare dengan yang tidak terkena diare. Rata-rata skor PHBS penderita 
Jika kepadatan hunian dan jarak antar rumah penduduk tidak terlalu berdekatan, hal ini sebagai upaya penanggulangan penyebaran penyakit diare (Notoatmodjo, 1995).

Perilaku hidup bersih dan sehat seseorang ternyata berpengaruh terhadap kejadian diare. Hal ini kemungkinan terjadi karena kondisi lingkungan yang sangat bisa mendukung penyebaran diare, diantaranya adalah pemakaian sumber air bersih untuk keperluan air minum, mandi dan masakmemasak. Selain itu, faktor jamban yang dipakai juga berpengaruh, misalnya masyarakat yang bertempat tinggal di daerah tepi sungai, mereka tidak mempunyai jamban sehingga buang air besar di sungai. Di wilayah kerja Puskesmas Delanggu, cakupan penggunaan jamban yang berhasil dicapai sebesar 38\% dari angka standar yang ditetapkan sebesar $65 \%$. Kemungkinan, hai ini dapat disebabkan masyarakat yang mempunyai jamban keluarga, beberapa masih jauh dari memenuhi syarat. Jarak antara sumber air dengan tempat peresapan kotoran manusia jaraknya $<10 \mathrm{~m}$, hal ini menimbulkan air sumur yang dipakai mudah terkontaminasi kuman dari kotoran manusia. Perilaku masyarakat dalam penanaman kebersihan lingkungan masih sangat kurang. Kebiasaan mencuci tangan dengan sabun sebelum makan maupun sesudah buang air besar masih jarang dilakukan oleh masyarakat.

Budiarso (1983) menyatakan bahwa untuk menekan insiden diare dan sekaligus mencegah timbulnya penyakit faecal-oral lainnya dapat dilakukan dengan memperbaiki keadaan higiene dan sanitasi lingkungan keluarga. Sesuai hasil penelitian yang peneliti lakukan, bahwa pengukuran perilaku hidup bersih dan sehat seseorang dilakukan dengan menggunakan indikator yang terdiri dari 16 pertanyaan yang mencakup mengenai 9 indikator perilaku dan 7 indikator lingkungan.

Upaya pemberantasan kejadian diare terutama penurunan episode dan durasi diare, tidak hanya terfokuskan pada faktor kesehatan lingkungan. Kebiasaan dan perilaku hidup sehat juga harus mendapatkan perhatian. Kebiasaan dan perilaku keluarga yang baik dalam menyediakan air bersih, membuang sampah pada tempatnya, penyediaan sarana pembuangan tinja yang baik dapat mengurangi episode diare.

Dalam menurunkan episode diare, tidaklah cukup dengan mengharapkan pembangunan kakus dan penggunaannya. Program juga harus meliputi komponen perilaku hidup yang sehat dan bersih juga, diantaranya dengan mencuci tangan baik sebelum dan sesudah makan maupun sesudah buang air besar, mengkonsumsi air bersih dan menjaga kebersihan makanan dan minuman dari pencemaran (LaFond UNICEF, 1995).

\section{KETERBATASAN PENELITIAN}

1. Keterbatasan dalam mengendalikan variabelvariabel pengganggu yang mempengaruhi hasil penelitian.

2. Hasil penelitian ini terbatas pada populasi yang diambil.

\section{KESIMPULAN DAN SARAN}

\section{A. Kesimpulan}

1. Ada hubungan yang bermakna antara Perilaku Hidup Bersih dan Sehat dengan kejadian diare di wilayah kerja Puskesmas Delanggu, dengan taraf hubungan sedang.

2. Rata-rata skor PHBS (Perilaku Hidup Bersih dan Sehat) yang terkena diare lebih rendah secara signifikan daripada yang tidak terkena diare.

\section{B. Saran}

1. Untuk pengembangan program, penyuluhan dan pendidikan untuk hidup bersih dan sehat, lebih menyentuh pada kelompok sasaran keluarga 
berpendapatan rendah dan memiliki sanitasi lingkungan yang rendah.

2. Upaya pemberantasan penyakit diare terutama penurunan episode dan durasi diare, tidak hanya memperhatikan keadaan kesehatan lingkungan tidak baik, kebiasaan dan perilaku hidup sehat keluarga perlu mendapat perhatian.

3. Penulis mengharapkan dapat dilakukan penelitian selanjutnya mengenai faktorfaktor lain yang mempengaruhi dan berhubungan dengan kejadian diare.

\section{DAFTAR PUSTAKA}

1. Budiarso, L.R. 1983., Sebab kematian bayi dan anak balita survei kesehatan rumah tangga 1980. Sumber: Buletin penelitian kesehatan Depkes, Jakarta.

2. Dainur., 1997. Materi-materi Pokok ilmu kesehatan Masyarakat. Widya Medika, Jakarta.

3. Departemen Kesehatan RI., 2002. Panduan Manajemen PHBS Menuju Kabupaten/Kota Sehat. Depkes RI, Jakarta.

4. Dinas Kesehatan dan Kesejahteraan Sosial Kabupaten Klaten., 2003. Profil Kesehatan Kabupaten Klaten Tahun 2003. Dinkes Kota Klaten, Klaten.

5. Lafond UNICEF., 1995. Hygiene and Sanitation Promotion : Why. Promote Sanitation.

http//:www.worldbank.org/watsan/hsp/hsp _whypromote.html

6. Notoatmodjo, S., 1993. Pendidikan Kesehatan dan IImu Perilaku Kesehatan. Andi Offset, Yogyakarta.
7. Notoatmodjo, S., 1997. IImu Kesehatan Masyarakat : Prinsip-prinsip dasar. Rineka Cipta, Jakarta.

8. Pusat pelayanan Kesehatan dan Kesejahteraan Sosial Kecamatan Delanggu kabupaten Klaten., 2003. Laporan Tahunan PPKKS Delanggu Tahun 2003. PPKKS Delanggu, Delanggu.

9. Prasetya., 2003. Faktor-faktor yang Mempengaruhi Kejadian Diare di desa Madurejo Kecamatan Prambanan.FK UMY, Yogyakarta.

10. Rumbarar., 1995. Faktor-faktor resiko yang Mempengaruhi Terjadinya Diare pada Anak Balita di Unit Penyakit Anak RSU. Kulonprogo Yogyakarta.FK UGM, Yogyakarta.

11. Agustina., 1994. Hubungan Tingkat Pengetahuan Dengan Sikap dan Perilaku lbu Terhadap Pencegahan Diare Pada Anak Balita Di Desa Mangunan, Kecamatan Dlinggo, Bantul. FK UGM, Yogyakarta.

12. Soemirat, J., 2000. Epidemiologi Lingkungan. Gadjah Mada University Press, Yogyakarta.

13. Sudigdo,S., Sofyan, Ismael., 1995. Dasardasar Metodologi Penelitian Klinis. Binarupa Aksara, Jakarta.

14. Sunoto. 1990. Pendidikan Medik Pemberantasan Diare : Buku Ajar Diare. Depkes RI: Ditjen PPM \& PLP.

15. World Health Organization (WHO)., 2004. Global Water Supply and Sanitation Assesment. World Health Organization,Geneva. http//:www.who.int 